E-ISSN : 2549-6581

DOI: 10.21776/ub.JOIM.2020.004.03.4

Artikel Hasil Penelitian

Diterima : 6 Juli 2020

Direview : 16 September 2020

Dimuat : Desember 2020 - Maret 2021

\section{OPEN ACCESS}

Journal of Issues in Midwifer

\title{
Hubungan antara Frekuensi dan Durasi Diare dengan Kejadian Stunting pada Balita Usia 24-36 Bulan di Desa Kedungrejo Kecamatan Pakis
}

\author{
Zakiya Miladya Choiroh $^{\left.1^{*}\right)}$, Era Nurisa Windari ${ }^{2}$, Astri Proborini ${ }^{3}$ \\ ${ }^{1 *}$ Program Studi S1 Kebidanan, Fakultas Kedokteran, Universitas Brawijaya, Email: \\ zakiyamiladya13@gmail.com, Tlp: +628123266670 \\ ${ }^{2}$ Program Studi Profesi Bidan, Fakultas Kedokteran, Universitas Brawijaya, Email: \\ ersawindari28@gmail.com \\ ${ }^{3}$ Program Studi S1 Kebidanan, Fakultas Kedokteran, Universitas Brawijaya, Email: \\ Ap rini@yahoo.com
}

\begin{abstract}
Stunting is a condition where there a disruption of growth in body length or height that not by age. A history of infectious diseases are one of the direct factors that can cause this condition. Diarrhea is an infectious disease which if occurs continuously can cause a significant decrease in fluid levels in the body, causing interference in the absorption of nutrients. This study aimed to analyze the relationship between the frequency and duration of diarrhea with the incidence of stunting in children aged 24-36 months. The study used a case control design with the subjects of the case group was stunting toddlers with their mother while the control group was non-stunting toddlers with their mother in Kedungrejo village, District of Pakis with a total of 24 for each group. Data was collected by anthropometric measurements in toddlers and mothers were interviewed using a diarrhea history questionnaire that had been tested for validity and reliability. The bivariate analysis used Chi-Square test. The results showed that from of 48 subjects, the percentage of toddlers aged 24-36 months who had a history of frequent diarrhea frequency was $14,5 \%$ ( 7 children) and the percentage of toddlers who had a mean duration of long diarrhea was 33,3\% (16 children). Statistical test results showed that frequency of diarrhea was not significantly related $(p=1,000)$ but increased the risk of stunting by 1,4 times, while the duration of diarrhea was significantly related $(p=0,030)$ and increased the risk of stunting by 5,0 times. It can be suggested that counseling is needed to provide information to the public about the first aid of diarrhea in toddlers as to minimize delays in treatment and reduce the risk of stunting.
\end{abstract}

Key words: stunting, frequency of diarrhea, duration of diarrhea, toddler

\section{ABSTRAK}

Stunting adalah keadaan dimana terjadi gangguan pertumbuhan panjang badan atau tinggi badan yang tidak sesuai dengan pertambahan usia dan merupakan hasil jangka panjang dari kekurangan nutrisi. Riwayat penyakit infeksi merupakan salah satu faktor 
langsung yang dapat menyebabkan keadaan ini. Diare adalah salah satu penyakit infeksi yang apabila terjadi terus menerus dapat menyebabkan penurunan kadar cairan dalam tubuh secara bermakna sehingga menimbulkan gangguan dalam penyerapan zat gizi. Penelitian ini bertujuan untuk menganalisis hubungan antara frekuensi dan durasi diare dengan kejadian stunting pada balita usia 24-36 bulan. Penelitian menggunakan desain case control dengan subjek kelompok kasus adalah balita stunting dengan ibunya sedangkan kelompok kontrol adalah balita tidak stunting dengan ibunya di Desa Kedungrejo Kecamatan Pakis dengan jumlah 24 untuk masing-masing kelompok. Pengambilan data dilakukan dengan pengukuran antropometri pada balita dan ibu diwawancarai menggunakan kuesioner riwayat kejadian diare yang telah dilakukan uji validitas dan reabilitas. Analisis bivariat menggunakan uji Chi Square. Hasil penelitian menunjukkan bahwa dari 48 subjek, persentase balita usia 24-36 bulan yang memiliki riwayat frekuensi diare sering adalah $14,5 \%$ ( 7 anak) dan persentase balita yang memiliki rerata durasi diare panjang adalah 33,3\% (16 anak). Hasil uji statistik menunjukkan frekuensi diare tidak berhubungan signifikan $(p=1,000)$ namun meningkatkan risiko stunting sebesar 1,4 kali, sedangkan durasi diare berhubungan signifikan $(p=0,030)$ dan meningkatkan risiko stunting sebesar 5,0 kali.

Kata kunci: stunting, frekuensi diare, durasi diare, balita

*Korespondensi: Nama Penulis. Surel: zakiyamiladya13@gmail.com

\section{PENDAHULUAN}

Derajat kesehatan merupakan salah satu indikator suatu negara dikatakan memiliki Sumber Daya Manusia (SDM) yang berkualitas. Derajat kesehatan merupakan suatu cerminan kesehatan dari seseorang, kelompok, maupun masyarakat yang digambarkan dengan mortalitas, morbiditas, usia harapan hidup, dan status gizi masyarakat. Kesehatan anak di Indonesia masih menjadi perhatian utama karena sangat menentukan kualitas SDM di masa mendatang ${ }^{(1)}$. Bawah lima tahun (balita) merupakan periode penting dalam tumbuh kembang anak dan merupakan masa yang akan menentukan pembentukan fisik, psikis dan inteligensinya. Masa balita juga merupakan masa yang rentan terhadap masalah gizi dan kesehatan karena mayoritas kegiatan balita diisi oleh bermain di tempat yang memungkinkan untuk terkena infeksi berbagai penyakit ${ }^{(2)}$. Stunting adalah keadaan dimana terjadi gangguan pertumbuhan panjang badan atau tinggi badan yang tidak sesuai dengan pertambahan usia dan merupakan hasil jangka panjang dari kekurangn nutrisi. Stunting didefinisikan sebagai tinggi badan menurut umur (TB/U) dibawah -2SD dalam tabel Z-score yang menjadi referensi internasional. Stunting utamanya muncul pada 2-3 tahun pertama kehidupan anak dan merupakan hasil jangka panjang yang bersifat kronis, dimana pada usia tersebut merupakan puncak dari laju pertumbuhan anak sehingga memerlukan zat gizi yang banyak. ${ }^{3}$ Keadaan stunting dapat disebabkan oleh faktor langsung dan tidak langsung. Faktor langsung mencakup asupan makanan dan penyakit infeksi sedangkan faktor tidak langsung mencakup kondisi ketahanan pangan rumah tangga, pola asuh, serta kondisi ekonomi keluarga balita ${ }^{(4)}$. Prevalensi balita stunting di Indonesia pada tahun 2018 termasuk kedalam negara ke-3 tertinggi di regional Asia Tenggara yaitu $37,2 \%$. Untuk wilayah Provinsi Jawa Timur mencapai mengalami penurunan dari $35,8 \%$ pada tahun 2013 menjadi $32,81 \%$ pada tahun 2018 dimana angka ini 
masih cukup jauh dari target penurunan stunting pemerintah Indonesia melalui Sistem Perencanaan Pembangunan Nasional yaitu $28 \%$ pada tahun $2019^{(5)}$.

Diare merupakan salah satu penyakit infeksi yang dapat menyebabkan gangguan penyerapan bahkan hilangnya zat gizi dan apabila tidak segera ditangani dan diimbangi dengan asupan yang sesuai maka akan terjadi gagal tumbuh ${ }^{(6)}$. Selain itu, saat anak mengalami diare, anak akan kehilangan nafsu makan sehingga asupan nutrisi berkurang dan nutrisi yang dikonsumsipun tidak diserap dengan baik oleh tubuh. Hal tersebut mengakibatkan berat badan yang mulai turun perlahan dan diikuti dengan pertumbuhan tinggi badan yang terhambat. Retardasi pertumbuhan berkaitan dengan turunnya hasil capaian pendidikan, kemampuan bekerja, capaian ekonomi saat masa dewasa, dan meningkatkan risiko terjadinya penyakit kronis ${ }^{(7)}$. Penelitian yang dilakukan oleh Desyanti dkk (2017) menunjukkan bahwa balita yang termasuk dalam kategori sering mengalami diare ( $>2$ kali dalam 3 bulan terakhir) berisiko 3,619 kali lebih besar untuk mengalami stunting ${ }^{(6)}$. Penelitian kohort prospektif yang dilakukan dari Agustus 1989 hingga April 1998 di Brazilia juga menujukkan hasil bahwa terdapat hubungan yang signifikan pada balita yang sering mengalami diare saat usia 0-2 tahun dengan masalah pertumbuhan tinggi badan yang dapat menetap selama 1-5 tahun ${ }^{(8)}$. Angka kejadian diare pada balita di Kecamatan Pakis diketahui meningkat dari tahun sebanyak 645 pada 2013 menjadi 1055 pada tahun 2014 ${ }^{(9)}$. Berdasarkan studi pendahuluan pada bulan Oktober
2019, Kecamatan Pakis menempati urutan ke-3 dengan prevalensi stunting tertinggi di Kabupaten Malang yaitu $30,7 \%$ dan terdapat daerah lokus stunting yakni Desa Kedungrejo. Berdasarkan hal ini peneliti ingin melakukan analisis hubungan antara frekuensi dan durasi diare dengan kejadian stunting pada balita usia 24-36 bulan di Desa Kedungrejo Kecamatan Pakis.

\section{METODE PENELITIAN}

\section{Rancangan/Desain Penelitian}

Penelitian ini menggunakan desain observasional analitik dengan pendekatan case control, yang juga dikenal dengan sifat retrospektif yaitu melihat kebelakang dari suatu kejadian yang berhubungan dengan kejadian kesakitan yang diteliti ${ }^{(10)}$.

\section{Sasaran Penelitian}

Populasi penelitian adalah balita di Desa Kedungrejo Kecamatan Pakis Kabupaten Malang sebanyak 450 balita. Subjek penelitian dipilih menggunakan teknik simple random sampling dengan kriteria inklusi yaitu balita berusia 24-36 bulan beserta ibunya yang bersedia mengikuti penelitian, dan kriteria eksklusi yaitu balita yang mengalami gangguan mental, cacat bawaan, dan sindrom lainnya. Besar subjek yang dibutuhkan berdasarkan rumus untuk desain penelitian case control dengan kemaknaan 95\% dan kekuatan 90\% adalah sebanyak 24 orang untuk kelompok kasus maupun kontrol. Dalam menentukan subjek untuk kelompok kasus maupun kontrol dilakukan pengukuran antropometri di salah satu posyandu di Desa Kedungrejo, kemudian ibu dari balita yang memenuhi kriteria inklusi akan diwawancarai dengan kuesioner riwayat penyakit diare balita yang 
telah diuji validitas dan reabilitasnya. Kelompok kasus adalah balita usia 24-36 bulan yang memenuhi kriteria pada tabel $z$-score $\mathrm{TB} / \mathrm{U}<-2 \mathrm{SD}$ dan usia median $\mathrm{BB} / \mathrm{U}<\mathrm{TB} / \mathrm{U}<$ usia kronologis (TB/U: tinggi badan menurut umur, BB/U: berat badan menurut umur) ${ }^{(11),}$ sedangkan kelompok kontrol adalah balita usia 24-36 yang tidak memenuhi kriteria tersebut. Kategori frekuensi diare yang digunakan adalah sering apabila mengalami diare $>2$ kali dan jarang apabila balita mengalami diare $\leq 2$ kali dalam 3 bulan terakhir ${ }^{(6)}$, sedangkan untuk kategori durasi diare yang digunakan adalah panjang apabila balita memiliki rerata durasi diare selama $>3$ hari dan pendek apabila rerata durasi diare selama $\leq 3$ hari. Balita dikatakan mengalami diare apabila dalam 1 hari balita BAB lebih dari 3 kali dengan konsistensi lembek atau cair bahkan hanya berupa air saja ${ }^{(12)}$.

\section{Teknik Analisis Data \\ Analisis}

bivariat

menggunakan uji Chi-Square dengan $\alpha=0,05$ untuk mengetahui hubungan serta uji OR untuk mengetahui besar risiko.

\section{HASIL PENELITIAN Karakteristik Responden}

Tabel 1 menunjukkan bahwa dari 48 responden yang mengikuti penelitian, persentase tertinggi usia ibu dari kelompok balita stunting maupun tidak adalah rentang usia 2635 tahun yaitu 41,7\% (10 orang) dan $62,5 \%$ (15 orang). Pendidikan terakhir ibu untuk kedua kelompok didominasi tamat SD yaitu sebanyak 13 orang $(54,2 \%)$ dan 11 orang (45,8\%). Pada kelompok balita stunting maupun tidak, mayoritas pekerjaan ibu adalah ibu rumah tangga yaitu sebanyak 22 orang $(91,7 \%)$ dan 16 orang $(66,7 \%)$. Kedua kelompok juga didominasi ibu dengan tinggi badan $>145 \mathrm{~cm}$ sebanyak 20 orang $(83,3 \%)$ dan 21 orang $(87,5 \%)$. 
Tabel 1. Distribusi Frekuensi Responden Berdasarkan Karakteristik Ibu

\begin{tabular}{|c|c|c|c|c|}
\hline \multirow{2}{*}{ Karakteristik Ibu } & \multicolumn{2}{|c|}{ Balita Stunting } & \multicolumn{2}{|c|}{ Balita Tidak Stunting } \\
\hline & Jumlah & $\%$ & Jumlah & $\%$ \\
\hline \multicolumn{5}{|l|}{ Usia } \\
\hline$\leq 25$ tahun & 7 & $29,2 \%$ & 5 & $20,8 \%$ \\
\hline $26-35$ tahun & 10 & $41,7 \%$ & 15 & $62,5 \%$ \\
\hline $36-45$ tahun & 6 & $25,0 \%$ & 4 & $16,7 \%$ \\
\hline$>45$ tahun & 1 & $4,2 \%$ & 0 & $0,0 \%$ \\
\hline Total & 24 & & 24 & \\
\hline \multicolumn{5}{|l|}{ Pendidikan } \\
\hline SD & 13 & $54,2 \%$ & 11 & $45,8 \%$ \\
\hline SMP & 7 & $29,2 \%$ & 8 & $33,3 \%$ \\
\hline SMA & 3 & $12,5 \%$ & 3 & $12,5 \%$ \\
\hline \multirow[t]{2}{*}{ S1 } & 1 & $4,2 \%$ & 2 & $8,3 \%$ \\
\hline & 24 & & 24 & \\
\hline \multicolumn{5}{|l|}{ Pekerjaan } \\
\hline PNS & 0 & $0,0 \%$ & 1 & $4,2 \%$ \\
\hline Pegawai Swasta & 1 & $4,2 \%$ & 4 & $16,7 \%$ \\
\hline Pedagang/wiraswasta & 1 & $4,2 \%$ & 2 & $8,3 \%$ \\
\hline Buruh & 0 & $0,0 \%$ & 1 & $4,2 \%$ \\
\hline Ibu Rumah Tangga & 22 & $91,7 \%$ & 16 & $66,7 \%$ \\
\hline Total & 24 & & 24 & \\
\hline \multicolumn{5}{|l|}{ Tinggi Badan } \\
\hline$\leq 145 \mathrm{~cm}$ & 4 & $16,7 \%$ & 3 & $12,5 \%$ \\
\hline$>145 \mathrm{~cm}$ & 20 & $83,3 \%$ & 21 & $87.5 \%$ \\
\hline Total & 24 & & 24 & \\
\hline
\end{tabular}

Tabel 2 menunjukkan bahwa dari 48 balita yang mengikuti penelitian, pada kelompok stunting lebih banyak balita perempuan sedangkan pada kelompok tidak stunting lebih banyak balita laki-laki dengan persentase yang sama yaitu $54,2 \%$ (13 anak). Persentase tertinggi untuk urutan anak pada kedua kelompok adalah urutan anak kedua yaitu $54,2 \%$ (13 anak) dan 45,8\% (11 anak). Pada kedua kelompok juga didominasi oleh balita yang memiliki riwayat berat lahir $\geq 2500$ gram yaitu sebanyak 22 anak $(91,7 \%)$ dan 23 anak $(95,8 \%)$. 
Tabel 2. Distribusi Frekuensi Responden Berdasarkan Karakteristik Balita

\begin{tabular}{|c|c|c|c|c|}
\hline \multirow{2}{*}{ Karakteristik Balita } & \multicolumn{2}{|c|}{ Stunting } & \multicolumn{2}{|c|}{ Tidak Stunting } \\
\hline & Jumlah & $\%$ & Jumlah & $\%$ \\
\hline \multicolumn{5}{|l|}{ Jenis Kelamin } \\
\hline Laki-laki & 11 & $45,8 \%$ & 13 & $54,2 \%$ \\
\hline Perempuan & 13 & $54,2 \%$ & 11 & $45,8 \%$ \\
\hline Total & 24 & & 24 & \\
\hline \multicolumn{5}{|l|}{ Urutan Anak } \\
\hline Pertama & 8 & $33,3 \%$ & 9 & $37,5 \%$ \\
\hline Kedua & 13 & $54,2 \%$ & 11 & $45,8 \%$ \\
\hline Ketiga & 3 & $12,5 \%$ & 3 & $12,5 \%$ \\
\hline Keempat & 0 & $0,0 \%$ & 1 & $4,2 \%$ \\
\hline Total & 24 & & 24 & \\
\hline \multicolumn{5}{|l|}{ Berat Lahir } \\
\hline & 2 & $8,3 \%$ & 1 & $4,2 \%$ \\
\hline$\geq 2500$ gram & 22 & $91,7 \%$ & 23 & $95,8 \%$ \\
\hline Total & 24 & & 24 & \\
\hline \multicolumn{2}{|c|}{$\begin{array}{l}\text { Analisis Univariat } \\
\text { Tabel } 3 \text { menunjukkan bahwa } \\
\text { dari } 48 \text { responden yang mengikuti } \\
\text { penelitian, persentase tertinggi } \\
\text { frekuensi diare adalah dalam kategori } \\
\text { jarang yaitu } 83,3 \% \text { (20 orang) dan }\end{array}$} & $\begin{array}{l}\text { kelompok } \\
\text { sebanyak } \\
\text { sedangkan } \\
\text { stunting } \\
\text { pendek d } \\
\text { yaitu } 50 \% \text {. }\end{array}$ & $\begin{array}{l}\text { balita tidak } \\
20 \text { ane } \\
20 \text { pada kelc } \\
\text { persentase } \\
\text { lan panjang }\end{array}$ & $\begin{array}{l}\text { ting yaitu } \\
(83,3 \%) \\
\text { k balita } \\
\text { si diare } \\
\text { ah sama }\end{array}$ \\
\hline
\end{tabular}
$87,5 \%$ (21 orang). Persentase durasi diare pendek lebih tinggi pada

Tabel 3. Frekuensi dan Durasi Diare pada Balita

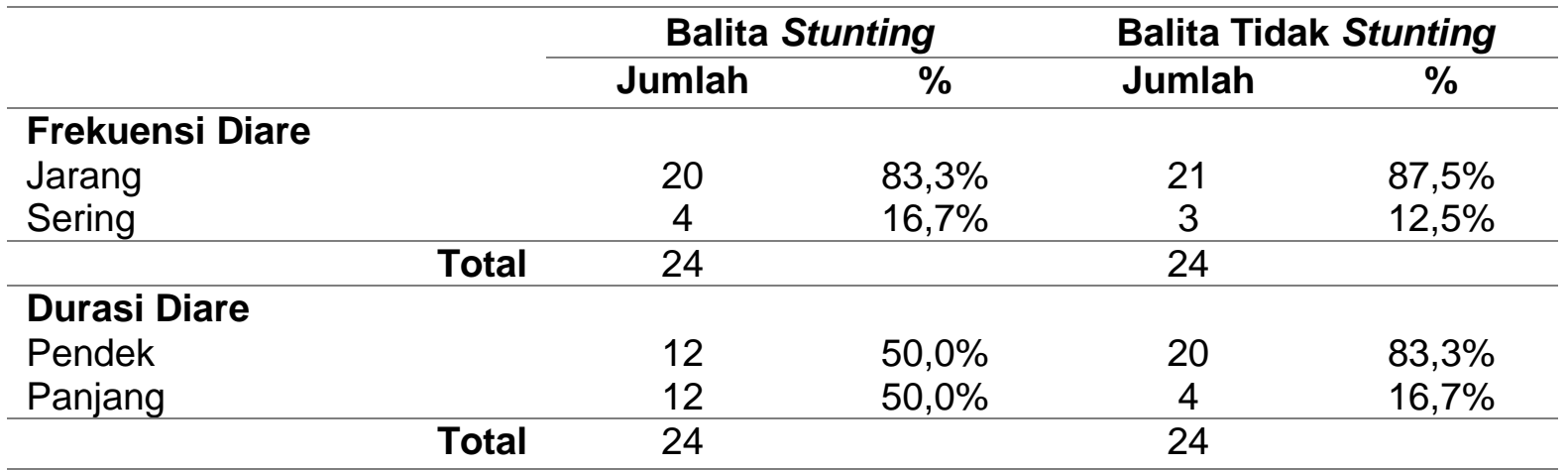

\section{Analisis Bivariat}

Tabel 4 menunjukkan bahwa frekuensi diare pada kelompok balita stunting maupun tidak stunting tidak terdapat perbedaan yang begitu signifikan. Berdasarkan uji Chi Square dengan menggunakan program SPSS versi 26.0 menunjukkan hasil dari $P$ value sebesar $1,000(p>0,05)$ maka dapat disimpulkan bahwa tidak terdapat hubungan yang signifikan antara frekuensi diare dengan kejadian stunting pada balita usia 24-36 bulan di Desa Kedungrejo Kecamatan Pakis, namun diperoleh nilai OR 1,4 yang artinya adalah balita yang sering mengalami diare berisiko mengalami stunting 1,4 kali lebih besar daripada balita yang jarang mengalami diare. 
Pada tabel 4 juga ditunjukkan bahwa diare dengan durasi panjang lebih banyak dialami oleh kelompok balita stunting yaitu sebanyak 12 anak. Analisis antara durasi diare dengan kejadian stunting mendapat hasil dari $P$ value sebesar 0,030 ( $p<$ $0,05)$ maka dapat disimpulkan bahwa terdapat hubungan yang signifikan antara durasi diare dengan kejadian stunting pada balita usia 24-36 bulan di Desa Kedungrejo Kecamatan Pakis, kemudian diperoleh nilai OR sebesar 5,0 yang artinya adalah balita yang mengalami diare dengan durasi panjang berisiko mengalami stunting 5 kali lebih besar daripada balita yang mengalami diare dengan durasi pendek.

Tabel 4. Analisis Hubungan antara Frekuensi dan Durasi Diare dengan Kejadian Stunting pada Balita Usia 24-36 Bulan di Desa Kedungrejo Kecamatan Pakis

\begin{tabular}{|c|c|c|c|c|c|c|c|}
\hline & \multicolumn{2}{|c|}{ Kejadian Stunting } & \multirow{2}{*}{ Total } & \multirow{2}{*}{$\begin{array}{c}P \\
\text { value }\end{array}$} & \multirow{2}{*}{$\begin{array}{c}\text { Odds } \\
\text { Ratio } \\
\text { (OR) }\end{array}$} & \multirow[b]{2}{*}{$95 \% \mathrm{Cl}$} \\
\hline & & Stunting & Tidak & & & & \\
\hline \multirow{2}{*}{$\begin{array}{l}\text { Frekuensi } \\
\text { Diare }\end{array}$} & Sering & 4 & 3 & 7 & \multirow{3}{*}{1,000} & \multirow{3}{*}{1,4} & \multirow{3}{*}{$0,278-7,056$} \\
\hline & Jarang & 20 & 21 & 41 & & & \\
\hline \multicolumn{2}{|c|}{ TOTAL } & 24 & 24 & & & & \\
\hline \multirow{2}{*}{$\begin{array}{l}\text { Durasi } \\
\text { Diare }\end{array}$} & Panjang & 12 & 4 & 16 & \multirow{3}{*}{0,030} & \multirow{3}{*}{5,0} & \multirow{3}{*}{$1,311-19,074$} \\
\hline & Pendek & 12 & 20 & 32 & & & \\
\hline \multicolumn{2}{|c|}{ TOTAL } & 24 & 24 & & & & \\
\hline
\end{tabular}

\section{PEMBAHASAN}

\section{Frekuensi Diare dengan Stunting} Hasil penelitian ini menunjukkan balita yang mengalami diare sering dalam 3 bulan terakhir adalah sebesar 14,5\%. Tingkat kejadian diare pada balita usia 24-59 bulan menurut WHO pada tahun 2010 di wilayah Asia Tenggara adalah sekitar 2 kali diare dalam satu tahun, namun tingkat kejadian diare pada balita di suatu daerah sangat dipengaruhi oleh variasi musim di daerah itu sendiri. Penyakit diare pada balita di daerah berpenghasilan rendah dan menengah memiliki tingkat kejadian lebih tinggi karena persediaan air bersih dan sanitasi yang tidak memadai serta asupan gizi yang tidak optimal seperti air susu, zat besi, dan vitamin $A^{(13)}$. Meskipun persediaan air bersih tercukupi dan sanitasi perlu untuk pencegahan penyakit diare pada balita, hal tersebut belum cukup kecuali disertai dengan perubahan perilaku kebersihan rumah tangga yang baik $^{(14)}$.

Hasil analisis hubungan antara frekuensi diare dengan kejadian stunting mendapatkan nilai $P$ value sebesar $1,000(p>0,05)$ dengan nilai OR 1,4. Hal ini menunjukkan bahwa frekuensi diare selama 3 bulan terakhir dengan kejadian stunting pada balita usia 2436 bulan di Desa Kedungrejo Kecamatan Pakis tidak memiliki hubungan secara statistik, namun bermakna karena didapatkan nilai OR 1,4 yang artinya balita dengan riwayat diare sering lebih berisiko menjadi stunting $1,4 \quad$ kali dibandingkan dengan balita yang memiliki riwayat diare jarang. Hasil ini tidak serupa dengan penelitian yang dilakukan oleh Musyayadah dkk pada tahun 2019 di Surabaya dimana pada penelitian tersebut menunjukkan hasil terdapat adanya hubungan yang signifikan antara riwayat penyakit 
diare dengan kejadian stunting pada balita. Pada penelitian tersebut dijelaskan bahwa infeksi yang masuk ke dalam tubuh akan merespon peningkatan sitokin Tumor Necrosis Factor- alpha (TNF- $\alpha$ ) dan Interleukin-1 (IL-1) ketika akan terjadi peradangan yang merupakan salah satu sistem pertahanan tubuh terhadap benda asing. Sitokin TNF- $\alpha$ dan IL-1 yang meningkat akan menurunkan hormon Insulin-like Growth Factor-1 (IGF-1) yang merupakan hormon pertumbuhan. IGF-1 yang menurun akan mempengaruhi pertumbuhan lempeng epifisis tulang panjang sehingga pertumbuhan linier anak tidak maksimal ${ }^{(15)}$. Perbedaan hasil pada penelitian ini dapat disebabkan karena kategori diare sering dalam penelitian ini berbeda dengan kategori yang digunakan oleh Musyayadah dkk di Surabaya. Hasil pada penelitian ini serupa dengan penelitian yang dilakukan di Kota Surakarta pada tahun 2011 oleh Kholifasari dkk yang menunjukkan hasil tidak terdapat perbedaan yang signifikan frekuensi diare antara anak stunted dengan anak tidak stunted ${ }^{(16)}$. Hal ini disebabkan karena stunting tidak hanya dipengaruhi oleh frekuensi penyakit infeksi, tetapi juga dipengaruhi oleh durasi penyakit infeksi dan asupan nutrien selama episode penyakit infeksi tersebut ${ }^{(12)}$.

\section{Durasi Diare dengan Stunting}

Hasil penelitian ini juga menunjukkan lebih banyak balita yang mengalami diare panjang pada kelompok balita stunting daripada pada kelompok balita tidak stunting, sedangkan untuk persentase keseluruhan balita yang memiliki rerata durasi diare panjang adalah sebesar 33,3\%. Anak-anak yang tinggal di daerah berpenghasilan menengah kebawah memiliki tingkat keparahan kasus yang lebih tinggi dibandingkan dengan anak-anak yang tinggal di daerah berpenghasilan menengah keatas karena kurangnya akses ke perawatan kesehatan yang berkualitas dan perawatan yang tepat waktu dan efektif dengan penanganan utama rehidrasi oral ${ }^{(13)}$. Akses pelayanan kesehatan yang dapat diperoleh masyarakat Desa Kedungrejo yaitu praktik bidan mandiri dan Puskesmas Kecamatan Pakis. Akses menuju Puskesmas Pakis sendiri yaitu $\pm 7 \mathrm{~km}$ dapat ditempuh kendaraan bermotor selama \pm 15 menit.

Hasil analisis hubungan antara durasi diare dengan kejadian stunting didapatkan nilai $P$ value sebesar $0,030(p<0,05)$ dengan nilai OR 5,0. Hal ini menunjukkan bahwa rerata durasi diare berhubungan signifikan dengan kejadian stunting pada balita usia 24-36 bulan di Desa Kedungrejo Kecamatan Pakis. Balita yang mengalami diare dengan rerata durasi lebih dari 3 hari berisiko 5 kali lebih besar untuk mengalami stunting. Hasil ini serupa dengan penelitian yang dilakukan oleh Ponamon dkk di Desa Kepondakan Kecamatan Kotamobagu pada tahun 2015 dimana menunjukkan terdapat hubungan bermakna antara durasi sakit balita dengan terjadinya stunting pada anak. Bayi dan anak merupakan masa pertumbuhan badan yang cukup pesat, sehingga memerlukan zat-zat gizi yang tinggi. Sayangnya, gangguan gizi dan infeksi sering terjadi secara bersamaan. Padahal apabila keduanya terjadi bersamaan akan memberikan dampak lebih buruk dibandingkan bila terjadi sendirisendiri. Infeksi dapat memperburuk taraf gizi, sebaliknya gangguan gizi 
juga dapat memperburuk kemampuan tubuh anak dalam mengatasi penyakit infeksi. Penyakit yang tidak menguras cadangan energi sekalipun jika berlangsung lama dapat mengganggu pertumbuhan karena menghilangkan nafsu makan anak ${ }^{(17)}$. Pada kondisi stunting ditemukan interaksi bolakbalik antara status gizi buruk dengan penyakit infeksi. Malnutrisi dapat meningkatkan risiko terjadinya penyakit infeksi sedangkan infeksi dapat menyebabkan malnutrisi. Apabila hal ini tidak segera diatasi dan terjadi dalam waktu yang lama, maka dapat mengganggu pengolahan asupan makan sehingga dapat meningkatkan risiko terjadinya stunting pada anak ${ }^{(18)}$. Diare merupakan salah satu penyakit infeksi metabolisme yang dampaknya dapat langsung dilihat dalam jangka waktu singkat, sedangkan keadaan stunting merupakan malnutrisi yang bersifat kronis dan merupakan dampak dari keadaan yang terjadi dalam waktu lama dan terusmenerus. Anak yang menderita penyakit infeksi dengan durasi waktu yang lebih lama, maka kemungkinan akan lebih besar mengalami kejadian stunting serta lebih cenderung mengalami gejala sisa (sekuel) akibat infeksi yang mana dapat melemahkan kondisi fisik anak. Zat besi merupakan mikronutrien esensial bagi tubuh dimana zat ini diperlukan dalam pembentukan molekul hemoglobin $(\mathrm{Hb})$, sehingga apabila jumlah zat besi dalam bentuk simpanan cukup, maka kebutuhan untuk pembentukan sel darah merah dalam sumsum tulang akan selalu terpenuhi. Akan tetapi jika tidak terpenuhi, maka terjadilah ketidakseimbangan zat besi di dalam tubuh dan balita akan mengalami risiko kekurangan besi. Kondisi tersebut akan menyebabkan terhambatnya pertumbuhan pada balita dan apabila berlangsung dalam waktu lama akan menyebabkan stunting pada anak ${ }^{(19)}$. Hasil yang berlawanan diperoleh pada penelitian oleh Tando (2012) di Kecamatan Malalayang Kota Manado, yang menunjukkan secara statistik tidak terdapat hubungan antara durasi sakit dengan terjadinya stunting, namun juga didapatkan nilai OR 2,08 yang artinya balita yang memiliki rerata durasi sakit $>3$ hari lebih berisiko 2 kali lebih besar menjadi stunting dibandingkan dengan balita yang memiliki rerata durasi sakit $\leq 3$ hari $^{(20)}$.

\section{SIMPULAN}

Tidak terdapat hubungan yang signifikan antara frekuensi diare dengan kejadian stunting pada balita usia 24-36 bulan di Desa Kedungrejo Kecamatan Pakis, namun ditemukan hubungan yang signifikan antara durasi diare dengan kejadian stunting.

\section{DAFTAR PUSTAKA}

1. Pratiwi, T.D., Masrul, M. and Yerizel, E., 2016. Hubungan pola asuh ibu dengan status gizi balita di wilayah kerja Puskesmas Belimbing Kota Padang. Jurnal Kesehatan Andalas, 5(3).

2. Fadzillah. 2016. Gambaran Pola Asuh dalam Pemenuhan Nutrisi Keluarga pada Balita Stunting Usia 24-59 Bulan di Wilayah Puskesmas Mulyorejo Kota Malang. Tugas Akhir. Tidak diterbitkan, Fakultas Kedokteran Universitas Brawijaya, Malang.

3. Sudiman H. Stunting atau Pendek: Awal Perubahan Patologis atau Adaptasi Karena Perubahan Sosial Ekonomi yang Berkepanjangan?. 
Media Litbang Kesehatan, 2008, 18(1): 33-43.

4. UNICEF. 2013. Improving Child Nutrition. UNICEF, New York, p. 811.

5. Kemenkes RI. 2018. Hasil Utama Riskesdas 2018 Provinsi Jawa Timur. Badan Penelitian dan Pengembangan Kesehatan Puslitbang Humaniora dan Manajemen Kesehatan.

6. Desyanti C., Nindya T.S. Hubungan Riwayat Penyakit Diare dan Praktik Higiene dengan Kejadian Stunting pada Balita Usia 24-59 Bulan di Wilayah Kerja Puskesmas Simolawang, Surabaya. Amerta Nutrition, 2017, 243-251.

7. Richard S.A., Black R.E., Gilman R.H., Guerrant R.L., Kanonyonag G., Lanata C.F., Molbak K., Rasmussen Z.A., Sack R.B., Valentiner-Branth P., Checkley W. Diarrhea in Early Childhood: Short-term Association With Weight and Long-term Association With Length. American Journal of Epidemiology, 2013, 178(7): 1129-1138.

8. Moore S.R., Lima A.A.M., Conaway M.R., Schorling J.B., Soares A.M., Guerrant R.L.. Early childhood diarrhoea and helminthiases associate with long-term linear growth faltering. International Journal of Epidemiology, 2001, 30: 1457-1464.

9. Ristiawan M. 2015. Hubungan Kualitas Bakteriologis Air HIPPAM dengan Kejadian Diare pada Balita di Wilayah Kerja Puskesmas Pakis Kabupaten Malang Tahun 2015. STIKES Widyagama Husada, Malang.

10. Hidayat, A.A.A. 2014. Metode Penelitian Keperawatan dan Teknis Analisis Data. Jakarta: EGC.

11. IDAI. 2019. How to Prevent Stunting: Detection and Manage Growth Deceleration Workshop. $3^{\text {rd }}$ Indonesian Pediatric Nutrition and
Metabolic Update (Nutrimet): All about Controversies in Nutrition and Metabolic. Indonesian Pediatric Society: Central Java Branch. Solo, 27-28 April.

12. Setiawan E., Machmud R., Masrul. Faktor-Faktor yang Berhubungan dengan Kejadian Stunting pada Anak Usia 24-59 Bulan di Wilayah Kerja Puskesmas Andalas Kecamatan Padang Timur Kota Padang Tahun 2018. Jurnal Kesehatan Andalas, 2018, 7(2): 275-284.

13. Fischer Walker, C.L., Perin, J., Aryee, M.J. et al. Diarrhea incidence in lowand middle-income countries in 1990 and 2010: a systematic review. BMC Public Health 12, 220 (2012). https://doi.org/10.1186/1471-2458-12220.

14. A. Strina, S. Cairncross, M. L. Barreto, C. Larrea, M. S. Prado, Childhood Diarrhea and Observed Hygiene Behavior in Salvador, Brazil, American Journal of Epidemiology, Volume 157, Issue 11, 1 June 2003, Pages 10321038, https://doi.org/10.1093/aje/kwg 075.

15. Musyayadah, M. dan Adiningsih, S., 2019. Hubungan Ketahanan Pangan Keluarga dan Frekuensi Diare dengan Stunting pada Balita di Kampung Surabaya. Amerta Nutrition, 3(4), pp.257-262.

16. Kholifasari, L. 2011. Perbedaan Frekuensi Morbiditas antara Anak Stunted dan Non Stunted di Lingkungan Kumuh Perkotaan di Wilayah Surakarta. Tugas Akhir. Fakultas IImu Kesehatan Universitas Muhammadiyah Surakarta.

17.Ponamon, N.S., Joy, A.M.R. and Maureen, I.P., 2015. Hubungan Antara Durasi dan Frekuensi Sakit Balita Dengan Terjadinya Stunting Pada Anak SD di Desa Kopandakan 1 Kecamatan Kotamobagu Selatan. Manado: Fakultas 
Kesehatan Masyarakat Universitas Samratulangi.

18. Pratama, B., Angraini, D.I. and Nisa, K., 2019. Penyebab Langsung (Immediate Cause) yang Mempengaruhi Kejadian Stunting pada Anak. Jurnal IImiah Kesehatan Sandi Husada, 10(2), pp.299-303.

19. Hidayani, W.R. and KM, S., 2020, April. Riwayat Penyakit Infeksi yang
Berhubungan dengan Stunting di Indonesia: Literatur Review. In Jurnal Seminar Nasional (Vol. 2, No. 01, pp. 45-53.

20. Ando, N.M., 2012. Durasi dan Frekuensi Sakit Balita Dengan Terjadinya Stunting Pada Anak SD Di Kecamatan Malalayang Kota Manado. Jurnal GIZIDO, 4(1), pp.338-348. 